\title{
Agricultural Supply Chain Risk Identification- A Case Finding from Ghana
}

\author{
Nyamah Edmond Yeboah ${ }^{1}$, Yi Feng ${ }^{1}$, Oppong-Sekyere Daniel ${ }^{2} \&$ Nyamaah Boadi Joseph $^{3}$ \\ ${ }^{1}$ School of Management and Economics, University of Electronic Science and Technology of China, Chengdu, \\ China \\ ${ }^{2}$ Department of Ecological Agriculture, Bolgatanga Polytechnic, Bolgatanga, Ghana \\ ${ }^{3}$ Ministry of Food and Agriculture (MOFA), Ghana \\ Correspondence: Nyamah Edmond Yeboah, School of Management and Economics, University of Electronic \\ Science and Technology of China, Chengdu 610054, China. E-mail: eddynaa@yahoo.com
}

Received: March 17, 2014

Accepted: April 21, $2014 \quad$ Online Published: May 4, 2014

doi:10.5430/jms.v5n2p31

URL: http://dx.doi.org/10.5430/jms.v5n2p31

\begin{abstract}
This paper investigate and identifies the probable supply chain related risks in Ghana agricultural supply chain and further seeks the severity of these risks based on engineering judgments and historical records. In addition, this paper probes into participants' ability level to manage/control the identified risk. The results indicate that, not all global supply chain related risks transpire in Ghana agricultural supply chain. While some risks such as market related risks are inevitable in the supply chain, others such as political related risk and some element of weather related risks do not exits and seldom occur in agricultural supply chain in Ghana respectively. Again, even though some risks are probable, their severity is minimal and at some point no severity at all. This research also indicates that participant of agricultural supply chain in Ghana have different abilities in managing/controlling risk in different risk in the chain. While there are no or weak abilities to manage/control financial related risks, the participant effectively manage/control risk that are from operational and managerial related.
\end{abstract}

Keywords: agricultural supply chain, risk, identification, probability, severity, Ghana

\section{Introduction}

Supply chain management has become a major part of companies/firms management systems due the numerous benefit associated to supply chains in todays' business environment. However, although such supply chain design changes and supply chain management initiatives have great potential to make operations leaner and more efficient in a stable environment, they simultaneously increase the fragility and vulnerability of supply chains to disruptions (Craighead, Blackhurst, Rungtusanatham, and Handfield 2007; Zsidisin, Ragatz, and Melnyk 2005). Several research have indicated the prevalent of disruptions to firms and its supply chain due to the unstable environment and the negative consequences of disruptions to firms (Martha and Subbakrishna, 2002; Chopra and Sodhi, 2004; Coleman, 2006; Hendicks and Singhal, 2005; Wagner and Bode, 2008). Therefore with the inborn of risk to modern supply chain, there is the need to single out and solve risks issues in supply chain management to achieve higher performance.

Risks management in supply chain is allied with cost, therefore before firms engage in such an expensive venture, there is the need to specify the type of industries to manage the risk and to identify the risks source that lead to the chains' disruptions. By identifying the risk, participant in supply chain could effectively manage the risks to minimize its' total cost which includes reducing future loss and damage.

Although, the benefits of an effective managed risk in supply chain to firms and national economies as a whole are well elaborated, not much research focus on agricultural supply chain risk. Meanwhile agricultural industries continuous to contributes to Gross Domestic Product (GDP) of many developing countries such as Ghana (Ghana statistical service, 2012) and contributes appreciably to developed countries (Kinsey 2001).

The role played by agriculture industries in Ghana's Gross Domestic Product (Ghana statistics 2012) and the possible detrimental effect of risks associated with supply chain management (Hendricks and Singhal, 2005; Lee et al. (1997) call for investigations into risk to aid in effective management of the chain. The agricultural industry 
contributes about $38 \%$ of the country's GDP annually. Ghana operates global agricultural supply chain (Ghana statistics 2012). The complexity of the system-wide network of the agricultural supply chain just like any other supply chain coupled with the perishability nature of produce involved in chain as well as the pressure on agricultural firms operating in an unstable environment to meet global competitive market could expose the chain to numerous risks (Martha and Subbakrishna, 2002; Chopra and Sodhi, 2004; Coleman, 2006; Hendicks and Singhal, 2005; Wagner and Bode, 2008). Therefore it's prudent to investigate the risk sources that could possibly affect the Ghana agricultural supply chain

Probing agricultural supply chain risk could go a long way to enable the chain's participant to manage the risk effectively which could increase the performance of the chain. However to the best of our awareness no recent research study has dived into identify risks, their severity and the ability to manage/control such risks. Thus, this research moves a step further to fill this gab.

The contributions of risks identification in supply chain are numerous. First probing agricultural supply chain risk in Ghana could go a long way to unearth the various risks affecting the chain. Secondly, enlightening these risks will enable the chains participants such as managers, governments/policies/decision makers to understand the risks exposure to agricultural supply chain in order to manage the chain effectively. In addition, this research will serve as a guide to new investors venturing to agricultural industries to have pre - knowledge of risks that transpires in the agricultural supply chain in Ghana.

By using Ghana as a case study, the main objectives of this research are in threefold (1) to identify existing risk in agricultural supply chain in Ghana (2) to seek these risks severity and (3) to find out the chain participants manage/control these risks effectively.

The subsequence section of this paper reviews the literature on definitions of risk, sources of agriculture supply chain risk and risk management. The follow up section addresses the methodology, approaches description of the study area and the case as well as the data collection. The results of the study are presented in section 4 . Section 5 discusses the findings and managerial implications. Finally, section 6 concludes the study and highlights future research.

\section{Literature Survey of Risk in Supply Chain and Its Management}

\subsection{A General Framework of Agricultural Supply Chain Risk}

Earlier research on of supply chain in general and agriculture supply chain or agricultural food chains indicate the chains' complexity network of multiple multifaceted firms usually working together within specific industrial sectors in a number of processes and activities to meet the customer demands and satisfactions (Christopher, 2005; Bryceson and Smith, 2008). An agricultural supply chain in Ghana encompasses all the input supply, production, intermediaries, processors, retailers, national/global markets. The operations in this chain get supportive services from logistical, financial and technical services which are basically controlled by the three flows in supply chain management; information, financial and material flows to effectively perform in an enabling environment.

With enough evidence of possible supply chain due to unstable environmental issues (Martha and Subbakrishna, 2002; Chopra and Sodhi, 2004; Coleman, 2006; Hendicks and Singhal, 2005; Wagner and Bode, 2008). We argue that risk events at any component/stages the chain can cause disruption and consequently undermine the performance of the chain. Participants in volatile agricultural supply chain could only effectively manage and mitigate risk if a detailed identification and descriptions of their root causes are known. Previous study indicates numerous supply chains risks in general could lead to a detrimental effect on the chain performance (Hendricks and Singhal, 2005). These risks include extreme weather related (Helferich and Cook, 2002; Hardaker et al., 2004), biological related risks (Baltussen et al. 2006; Palinskas and Szekely 2008), environment related risks ( Meuwissen et al. 2001; Huirne et al. 2007) and market related risk (Juttner, 2005; McKinnon, 2006; Nagurney et al., 2005; Wagner and Johnson, 2004; Fitzgerald 2005;Murphy 2007). Others are logistics and technologies related risks (Brimer, 1995; Tarantilis et al., 2004; Jaffee,et al.,2010), political risk (Cudahy et al., 2008; Ksoll, Macchiavello and Morjaria 2009), policy and institutional (Regulatory, legal and bureaucratic) related risks (Stiglitz 1998; Hendricks and Singhal 2003; Dorosh et al., 2009), financial related risk (Hartle-Urquhart, 2006; Peck et al., 2003; Tang, 2006b; Hendricks and Singhal, 2005) and managerial and operational related risks (Jaffee,et al., 2010).

Risk sources and its mitigations are geographical and business specific. Therefore it will be important to identify risks based on the area and specific industrial supply chain. To our knowledge, researches focusing on identification of risks in Ghana agricultural supply chain are lacking. Therefore, this paper fills this gap by unearthing the reality of 
risk in Ghana agricultural supply chain by identifying risks to seek its severity and the abilities of the supply chain participants to manage/control risks.

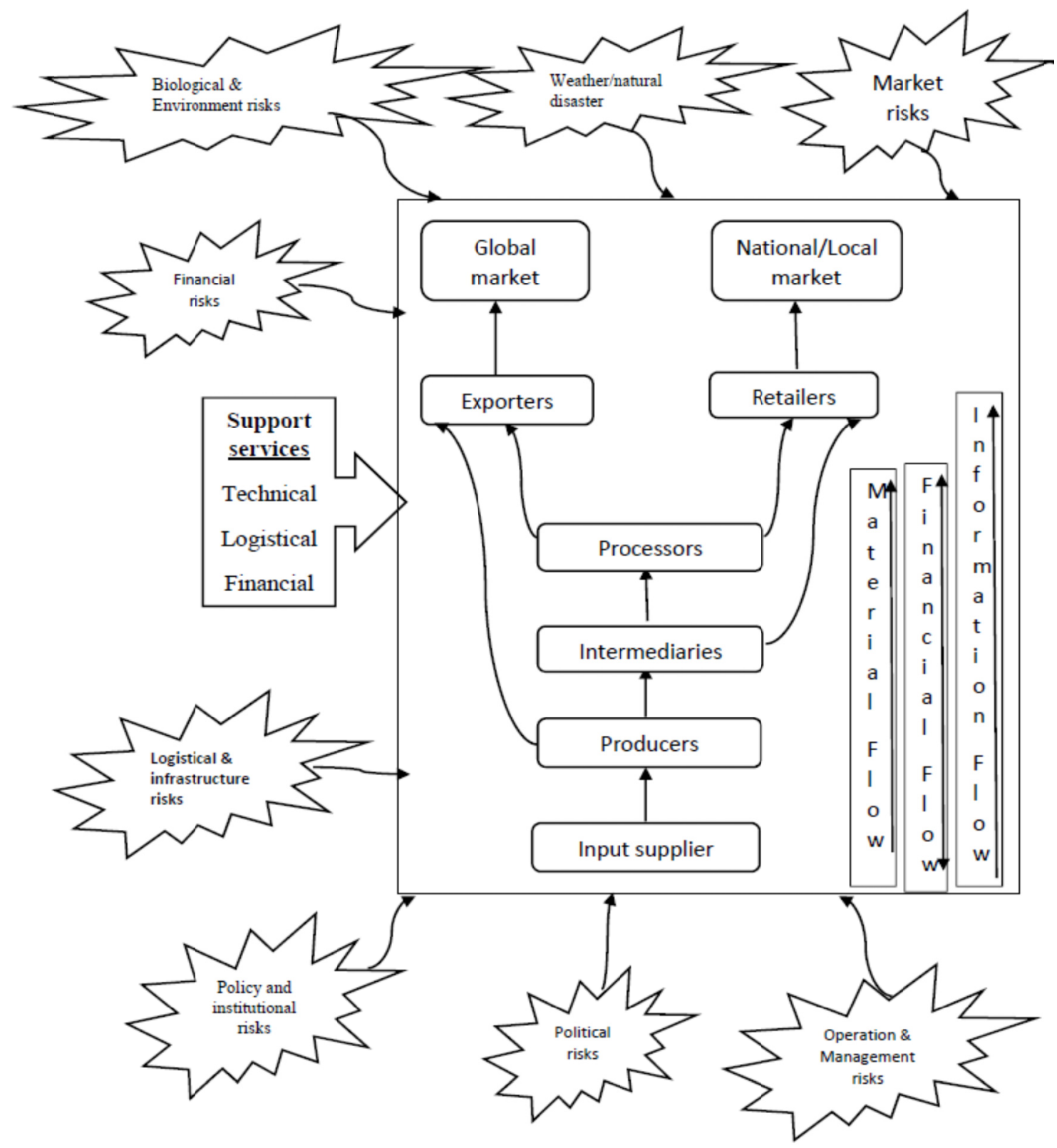

Figure 1. Structure of agriculture supply chain and potential sources of risks in Ghana

\subsection{Definitions of Agriculture Supply Chain Risk}

In dealing with issues concerning risk, supply risk or to be specific agricultural supply chain risks and its management, it is essential to first identify other words that may be similar in meaning to risk in literature and to define risks, supply risk, agricultural supply chain risks. The paragraph below tries to answer such questions.

Earlier research have revealed risk as an elusive construct that has a variety of meanings, measurements, interpretations depending and variety of risk characteristics on the field of research (Jemison 1987: Baird and Thomas 1990: Spekman and David 2004). Risk and uncertainty are both associated with exposure to circumstances that incur losses. Whereas risk can be defined as imperfect knowledge where the probabilities are known, uncertainty exists when these probabilities are unknown (Sigel, 2005). Thus, in the subsequence sections, this paper uses risk and uncertainty interchangeably since their outcome incur change in situation or losses. 
Risk is notably linked to events which result to negative effect and very small occasion positive effect. Quinn (2006) refers to risk as catastrophic events, which could probably change situations. According to Paulson (2005) risk is any event with negative economic consequences. Christopher and Lee (2004) define risk is an effect of external events such as terrorist attacks that can negatively impact changes in business strategy. By definition, Tang (2006) linked supply chain risk to the uncertainty of occurrence of an event that could affect one (or more) partner or link within the supply chain and that could influence (in a negative sense) the achievement of company's business objectives.

Risk has been defined as an operational as well as a disruption risks (Tang, 2006), however no distinguish were between them. According to Kersten et al., (2006) risk (in firms operation) is the damage assessed by its probability of occurrence caused by events within firms, its supply chain or its environment affecting the business process of at least one actor in the firms' supply chain.

Risk has been also been linked to inflow of typical supply chain network. Supply risk usually refers to the occurrence of uncertainties that may halt the inward flow of the supply chain (Harland et al., 2003; Zsidisin 2003; Tang 2006a). According to Zsidisin et al. (1999) supply risk is the transpiration of significant and/or disappointing failures with inbound goods and service.

According to Juttner et al, (2003) supply chain risk is a variation in the distribution of possible supply chain outcomes, their likelihood and their subjective value. Harland et al. (2003) for instance, discuss several definitions of risks and conclude that supply risk is associated with the chance of danger, damage, loss, injury or any other undesired consequences.

Many types of quantitative analysis have been revealed, but they are mostly based on two factors (1) likelihood of the risky event occurring and (2) severity when the event does occur. Therefore this research again define risk as a function of likelihood and severity (i.e. Risk $=f$ (Likelihood, Severity).

Risk or uncertainty is ever-present and varied within agriculture and its supply chain. These risks emerge from a range of external and internal factors of the supply chain environment. Therefore an agriculture supply chain could be define as a complex system (Bryceson and Smith, 2008), made of complex organizations involved in a number of processes and activities (Christopher, 2005) that collaborate strategically in one or more areas to meet a certain expected performance. Hence just like any other supply chain risk, an agricultural supply chain risk is defined in this paper as any eventual variation in agricultural supply chain activities that are associated with undesirable consequences that negatively affect the desired supply chain performance.

\subsection{Agricultural Supply Chain Risk Sources}

After the careful exploration of the definitions of risk in general in addition to supply chain risk and agricultural supply chain risk in viewpoint, it is prudent to categories the sources of these risks in order to put in place sound risk managerial policies. Next in this subsection, this paper present and discuss the important and common sources of agricultural supply chain risks and supply chain risk in general.

The categories of supply chain risk/uncertainty are often regarded as "supply chain risk sources". In an agricultural supply chain, risk can emerge either from internal or external environment of the supply chain. Chiefly amongst them are risk sources such as weather/natural disasters related as well as biological and environmental related. Others are market related risks, logistical and infrastructure related risk, political related risk, policy and institutional related risk, financial related risk and operational managerial related risks (Jaffee et al., 2010).

\subsubsection{Weather/ Natural Disasters Related Risk}

Niemira (2005) argues that weather influences sales primarily through its effect on economic activity. Broader and more systematic studies (Starr-McCluer 2000) document a significant impact of weather on retail sales at an aggregate level, although the primary effect may be that of shifting demand earlier or later. In agricultural supply chain, weather related risk such as periodic deficit and/or excess rainfall or temperature, hail storms and strong winds often affect agricultural supply chains (Jaffee,et al.,2010). In many regions extreme weather related risks have constant threat to societies in general and to firms in particular (Helferich and Cook, 2002). Rainfall shocks, and in particular drought, has been revealed to have significant and persistent effects on economic well-being (Maccini and Yang, 2009). These weather-related risks are mostly associated with yield reductions, but also can affect the quality of products and disrupt the flow of goods and services. In addition, these weather-related risks might impact logistics along the supply chain because of disruptions in transport, communications and energy services (Jaffee,et al., 2010). According to USDA report (2012), drought conditions affected approximately 80 percent of U.S. agricultural land in the summer of 2012. However these drought does not only have impact on farmers (raw material producers) in a given area, but also upstream buyers, processors and traders which in turns affects the entire supply chain performance. 
The inherent dependency of agricultural supply chain on the vagaries of weather such as rainfall is high. This leads to production risk which is one of the most important risk associated with weather related issues (Hardaker et al., 2004). This could consequently affect raw materials producers (farmers) ability to repay debt. Weather conditions affect greater share of business (agri-business) activities in parts of the globe display high sensitivity of agricultural to fluctuations in rainfall (Benson and Clay, 1998). Extremes weather and natural events related risk labelled as natural disasters such as flood, hurricanes, cyclones, typhoons, earthquakes and volcanic activities affects agricultural supply chain in many ways.

\subsubsection{Biological and Environmental Related Risk}

Biological and environmental risks affecting agricultural supply chains are ubiquitous and varied. These biological risks are usually associated with a very specific geographic location in the short-term, but can move through the entire supply chain (Jaffee,et al., 2010).

Biological related risks are mostly associated with malfunctions of gene expression and diseases. Baltussen et al. (2006) identified disease risk as highly importance among dairy, pig and poultry farming. According to Meuwissen et al. (2001) and Huirne et al. (2007) attribute high scores production risk to disease risk. Palinskas and Szekely (2008) show that contagious diseases represent the highest - scoring risk in crop farming followed by production risks. The presence of certain plant pests or livestock diseases may impinge upon international market access, not only for the farmers and firms immediately affected but perhaps for the entire agricultural chain. They can also have systemic impacts on decision-making and productivity and market options (Jaffee,et al., 2010).

The environment in which agricultural supply chains operates can determined the performance of the chain. Meuwissen et al. (2001) and Huirne et al. (2007) point to high importance of strict hygienic rules for output risk reduction for Dutch farmers. Environmental degradation could adversely affect (future) productivity, worker health, or downstream market access. As more and more commodity supply chains now feature the tracking/recording of raw materials back to their original sources, downstream buyers can no longer claim that they don't know how these raw materials are produced (Jaffee,et al.,2010). The adverse environmental foot print of some production practices therefore constitutes a potential commercial and reputational risk for downstream processors and distributors.

\subsubsection{Market Related Risks}

Agricultural supply chain just like any supply chain is associated with market related risk. These risks basically reside in demand and supply variations. Demand related risks result from disruptions emerging from downstream supply chain operations (Juttner, 2005). This includes on the one hand disruptions in the physical distribution of products to the end-customer with particular issues being transportation operations (McKinnon, 2006) and the distribution network. Demand side risks can originate from the uncertainty surrounding the random demands of the customers (Nagurney et al., 2005). Literature proves that demand uncertainties such as demand volatility are still the major problem discussed (Agrell et al., 2004; Sodhi, 2005; Zhang 2006; Ding et al., 2007).

In agricultural supply chain, demand related risks/volatility emerges as a result of a number of factors. Chiefly among them are (1) fluctuations in demand that impact domestic or international prices of inputs and/or output, (2) Changes in market demands for quantity and/or quality attributes, (3) changes in food safety requirements, (4) changes in market demand for timing of product delivery as well as (5) changes in supply chain reputation and dependability (Jaffee,et al., 2010).

The above demand related risks lead to disruptions in agricultural supply chain. Disruptions occur here from a mismatch between a company's projections and actual demand (forecast error) as well as from poor supply chain coordination. An important issue in this context, affecting forecast quality and therefore demand-side disruptions, is the bullwhip effect, which is characterized by an amplification of demand volatility in the upstream direction of the supply chain. Lee et al. (1997) analyzed this detrimental effect and identified delayed and distorted information, sales promotions, order batching, price fluctuations and rationing, or shortage gaming as major causes. Other factors intensifying the bullwhip effect are over-reactions, unnecessary interventions, second guessing, and mistrust (Christopher and Lee, 2004).

Supply related risks are various events that affect the continuity of the supplier and result in the temporary or permanent termination of the buyer-supplier relationship. For instance the threat of financial instability of suppliers could lead to supplier default, insolvency, or bankruptcy (Wagner and Johnson, 2004). Supply related risks include, production capacity constraints on the supply market, quality problems, technological changes, and product design changes. 
Fitzgerald (2005) links poor quality to incapability of the supplier to produce according to the standard demanded. Moreover, Murphy (2007) illustrates quality problem with products safety and contamination in China.

\subsubsection{Logistical and Infrastructure Related Risk}

Agricultural supply chains increasingly face risks related to logistics and infrastructure that affect the availability and timing of goods and services, energy and information. According to Jaffee, et al. (2010), failures in logistics are transmitted through the agricultural supply chain and could impact product quality and traceability as well as decision-making.

Effective logistics and technologies are critical success factors for both manufacturers (producers) and retailers (Brimer, 1995; Tarantilis et al., 2004). Effective logistics requires delivering the right product, in the right quantity, in the right quality, to the right place, at the right time, for the right cost (Aghazadeh, 2004). These leads to positive impact on the success of the partners in the supply chain (Brimer, 1995). Logistics/ infrastructure related risks are closely related driving decisions on product lines and input use, which can affect future production, processing, marketing decisions, commercial strategies and bargaining power (Jaffee,et al., 2010).

The multi - complex nature of agricultural supply chain networks requires well plan and design logistics to allow effective and efficient operation to interconnect the numerous nodes. Risks relating to transportation include rising energy cost, labour shortage, port congestion capacity constraint, service reliability reduction (Hauser, 2003; LaLonde, 2004, 2005). When logistics activities need to cross international borders, custom delays (Hauser, 2003) and long queues from tighter security (LaLonde, 2005) are also common phenomena that affects logistics services.

Information Technology (IT)-related problems are inclusive in logistics/ infrastructural risk and are highly relevant to supply chain management since many supply chain management functions build on information processing and sharing. Organizations have become increasingly technology-dependent and, consequently, vulnerable to IT problems or breakdowns (Chopra and Sodhi 2004).

\subsubsection{Political Related Risk}

Political risk is a major concern for companies in a wide range of industries. Globally, supply chain in general is subjected to political risks when the multi complex network extend over country boarders. A recent World Bank study indicated that more than half of all organizations believe that political risk will be the most important constraint on investment in emerging markets. In the same study, however, most of those organizations indicated they have no way of measuring political risk and do not integrate it into their approach to risk management (World Bank 2009). Cudahy et al. (2008) view political risk from the perspective of the sourcing country's political instability. Ksoll, Macchiavello and Morjaria (2009) in conducting a survey on Kenyan flower grower-exporters, showed that the December 2007 post-electoral conflict reduced cut flower exports by $24 \%$ overall, and by $38 \%$ for firms located in conflict areas, mainly through displacing workers. Whereas the authors could not provide evidence to suggest that the conflict affected export volumes in the areas not affected by the conflict nor the sensitivity of competitor countries behavior for the EU market their evidence showed that the conflict did change Kenyan exporters' behavior. Specifically, shipments were more consolidated and exported less frequently, while security expenses increased Ksoll, Macchiavello and Morjaria (2009). Stalk (2006) view outsourcing risk to China has little to do with the politics of import restriction, but that the main concern now are political barriers to port expansion. Checa et al. (2003) emphases that risks are associated with administration transition in a government.

\subsubsection{Policy and Institutional Related Risk}

Policy and institutional (Regulatory, legal and bureaucratic) risks have major impact on the structure of the agriculture supply (Jaffee,et al., 2010). Forms of regulation policy adopted in developing countries have shifted over time (Minogue, 2005). Following the apparent success of market liberalization programs in some developed countries, and the evidence of the failure of state-led economic planning in developing ones (World Bank, 1995), the role of state regulation was redefined and narrowed to that of ensuring an undistorted policy environment in which efficient markets could operate. It has been suggested that market failures may be more pronounced, when the case for public regulation is stronger, in developing countries (Stiglitz 1998). According to Hendricks and Singhal (2003, 2005a, 2005b) supply chain disruptions can be associated with the actions or decisions of authorities. Administrative barriers (customs, trade regulations) may restrict the design and influence the operative performance of supply chains. Legal changes are often sudden and difficult to anticipate and substantially increased transportation costs. Unpredictable and untimely changes in import tariff rates, ad hoc restrictions on private importation and the quest of firms to meet environmental requisites, frequently get involved in more complex supply chains and incur higher supply chain costs. During the first half of 2007, the Zambian government position on maize exports changed three 
times (Zinyama, 2007). Dorosh et al., (2009) mention export ban, large import close and open boarder as some of government policies on food. The frequent and unexpected change in policies surrounding agriculture supply chain could increase the risk along the chain.

\subsubsection{Financial Related Risk}

Financial flow in agricultural supply chain plays a major role in the complex network of organization that drives the entire supply chain to a desirable outcome. Without access to finance, productivity and market access suffer from constraints such as a) working-capital to finance production costs, including the purchase of improved seeds and insurance to protect investments from climatic fluctuations, b) investment capital for mechanization and other production, storage, and processing technology, and c) trade finance to help traders get a container to its destination.

In general financial related risk leads to the inability to settle payments and improper investments. Several research have attributed the financial risk to factors such as financial handling and practice, financial strength of supply chain partners exchange rate risk, etc.

Financial handling and managing has been a major problem in supply chain. Hartle-Urquhart (2006) discusses the risk arising from the way in which financial flows are managed and handled. Several researches have shown that the vulnerability of the financial strength of supply chain members could easily affect the entire supply chain (Peck et al., 2003; Tang, 2006b). Hendricks and Singhal (2005) report the vulnerability of financial flow and the long term effect associated with supply chain disruptions. They reveal that the affected firms' stock prices could be negatively influenced before the disruption announcement is made, whereas during the post announcement period, the firm firm's stock prices may have positive or negative development depending on their corrective actions. Exchange rate is another arm of finance that boost supply chain risk. Li et al. (2001) discuss the exchange rate risk and propose when to switch suppliers on the basis of the exchange rate risk.

The World Bank (2008) reported an evolutional change in agro- food sector. Despite the changes in agriculture and agribusiness, the typical offer for financial products and services for agricultural and rural production has been deficient and not particularly innovative; financial intermediaries still lack much depth in rural areas, and producers, especially smallholders, are still underserved. Conventional thinking is that the agricultural sector is too costly and risky for lending. Yet, major banks in the sector such as Rabobank and Banorte, large financial institutions in the Netherlands express the view that agricultural credit is profitable if producers are well integrated into a viable value chain (Shwedel, 2007).

\subsubsection{Operational and Managerial Related Risks}

There are numerous managerial and operational issues facing agricultural supply chain management. Some of the issues discussed in earlier research related in agricultural operation and managements includes inventory management of perishable products (Nahmias (2011), farm planning (Lowe and Preckel, 2004), food distribution management (Akkerman et al., 2010).

Agricultural operation and management risks are closely associated with human judgment and response such as errors in action and inaction, commission and omission and it directly affect a single chain participant, but could also be transmitted through the entire supply chain (Jaffee, et al., 2010). Managerial and operational related risks are part and parcel of decision-making from farms to firms. These risks are mostly associated with productivity reductions, and low quality of products, and unreliable delivery. There may be operational failures by one entity which spillover to losses (or lost market access) to many others and (Jaffee, et al., 2010)

\subsection{Agricultural Supply Chain Risk Management}

From the above sections, it is clear that agricultural supply chain is inevitable of risk. Supply chain risk are manage to achieve a desirable performance, therefore after reviewing the definitions of risk, supply chain risk and risk identification, it's prudent to dive into its management.

In this section, this paper review the possible definition of supply chain management and further look into supply chain risk management in general and agriculture supply chain in the later part.

Carter and Rogers (2008), viewed supply chain management as ability of a firm to understand and manage its economic, environmental and social risk in their supply chain by adoption of contingency planning and having a resilient and agile supply chains. According to Kouvelis et al. (2006) supply chain management is managing the uncertainty of demand, supply and costs. Tang (2006a) viewed supply chain risk management as the collaboration of supply chain partners in managing supply chain risk to ensure profitability and continuity. 
Other study relates supply chain resilience to supply chain risk management. According to Rice and Caniato (2003), supply chain resilience is the ability of an organization to react to an unexpected disruption and maintain operations after the event. Peck (2006) reveals that resilience brings the concept of an organization's ability to absorb or mitigate the impact of disturbance.

Some researches claim that there are gaps in supply chain risk management. Tang and Musa (2011) and Sodhi et al (2012) identify that (1) there is no clear definition of supply chain risk management definitions, (2) a lack in research on mitigating supply chain risk and (3) a clear deficiency of empirical studies in this area.

Supply chain risk management has been categorized by earlier research. Neiger et al.(2009) categories supply chain risk management into the process of risk identification, risk assessment, risk analysis and risk treatment. Risk management as a process of risk analysis subsequently followed by risk perception has been identified (Knemeyer et al., 2009). In the case of global supply chain, Manuj and Menser (2008) indicate that managing risk should at least comprise the processes of identification, evaluation and mitigation. They also propose the inclusion of time which follows similar ideas in Sheffi and Rice (2005) and frequency of risk along with the common risk dimensions, probability and impact.

Some researches have group risk management into two fundamental strategies. Holzmann and Jørgensen (2000) as well as Siegel and Alwang (1999) separate risk management into ex ante and ex post strategies. The ex-ante actions are taken before a risky event occurs, and ex post management takes place after its realization. Ex ante risk management includes (1) risk prevention or reduction, (2) reducing exposure to risk, (3) risk mitigation. The ex post activities cope with realized losses by migration, selling assets and bailout from governments.

Jaffee, et al. (2010) cited numerous instances in which agricultural supply chain risk can, potentially, be managed at different points and by different participant of the chain. Among these are (1) by individual farms and firms, through enterprise strategies, various management, (2) In supply chain integration with sharing of risk with participant, (3) at internal level, through joint action with other farmers and firms, cooperatives and industrial association and (4) at external level where other participant are outside boarders, banks, insurance companies, government agencies, donor agencies absorb major parts of the risk element through various financial instruments, physical stock-holding.

\section{Research Methods and Approaches}

\subsection{Approach}

With the nature of our research, we chose to adopt a case study methodology of research to understand the reality of risk exposure to participant in agricultural supply chain in Ghana. According to (Ellram, 1996) a case studies focus on holistic situations in real life settings. This could lead to best strategy to understand the whole complexity of an area of inquiry (Yin, 1984).

We studied the combine cases of participant in the major agricultural industries (Horticultural, Fish and Seafood and Process and industrial) to unearth the reality of risks affecting agricultural supply chain in Ghana. The reason behind these choices is that, they cover the main stream of agricultural supply chain that could be largely expose to risk in the agricultural industry due to the complexity of the network and its performance in global agricultural supply chain.

Ghana is typically an agricultural country with agricultural industries contributing almost $40 \%$ of its GDP and employing more than $60 \%$ of it populace (Ghana Statistical Service 2010).

This research formulates the interview question based on initial pool of scale items that had been generated through and extensive review of the academic and practitioner literature on supply chain risk in general but greater emphasis on those that could affect agricultural industries. The means of the individual risks categories identified is presented in the results sections

Next, initial contacts were made to several participants in the specified agricultural supply chain to explain this paper objectives to them and book an appropriate for the interviewed and data collection.

\subsection{Data Collection}

This research adopts a combination of data collection techniques to ensure the validity and rigorousness of the data used. The two major techniques are interview for a first-hand data and secondary data from different sources such as agencies report and some case industrial website. An earlier research suggest the techniques used in this paper (Yin, 1984; Ellram, 1996) as among the best techniques. 
A semi-structured interview base on the objectives of this research were used to seek the in depth knowledge from the interviewees and to allow free expression. During each interview, vital points concerning risks issues were jotted in manner not to deter interviewees from hammering more knowledge about the subject area.

The probability and severity of risk were grouped under four point scale; Not applicable (0) Low (1), Medium (2) and High (3) and Not applicable (0), Small (1), Medium (2) and Large (3) respectively. The probability measures the likelihood of the rest and severity index is based on engineering judgments and historical records. Also, the management/control which measures the ability of firms to manage/control the risk source were group into three point scale; No ability (1), weak ability (2) and Strong ability (3). The length of the interview varies based on the conditions on ground however, telephone calls and emails were standby tools for any clarifications and were also used to interview respondents afar. The interviewees consist of participants/players/actors in the agricultural supply chain of the major agricultural industries selected to enable this research to capture all risk issues in the sector. The locations of the interview were mostly at participants' work places which also aided the researcher to observe the reality on ground about the area of studies. All secondary data were either handed to the research team (with confidential warning notice) or downloaded from websites. The sample size and respondents percentages are shown in Table 1.

Table 1. Number of respondents $($ Total $=1077)$

\begin{tabular}{llllllll}
\hline & $\begin{array}{l}\text { Input } \\
\text { suppliers }\end{array}$ & Producers & $\begin{array}{l}\text { Intermediaries/ } \\
\text { Wholesalers }\end{array}$ & Processor & Retailers & Exporter & $\begin{array}{l}\text { Support } \\
\text { services }\end{array}$ \\
\hline Sample size & 131 & 257 & 276 & 103 & 200 & 34 & 76 \\
Percent-age & 12.16 & 23.86 & 25.63 & 9.56 & 18.57 & 3.16 & 7.06 \\
\hline
\end{tabular}

\section{Results}

\subsection{Weather/Natural Disaster Risk Identification}

The results on weather/natural disaster risk identification indicates that agricultural supply chain in Ghana is not influenced by extreme cold, hail storms, strong wings earthquake and volcanic which influence supply chain in other parts of the globe (Table 2). The most concerned weather/natural disaster risk in agricultural supply chain are periodic deficit (Table 2). Flooding agricultural supply chain in Ghana issues seldom occur and mostly its severity is low but could chain's operations. From the weather/natural disaster risk management/control abilities results, participants in the agricultural supply chain in Ghana have weak management/control abilities on risk emerging from periodic deficit rainfall but no ability to manage/control risk caused by extreme drought and flooding respectively. In addition, the participants of the chain have no management/control over periodic excess rainfall (Table 2).

Table 2. Weather/Natural disaster risk identification

\begin{tabular}{llll}
\hline & Probability & Severity & Management/Control score \\
\hline Periodic deficit rainfall & 2 & 2 & 2 \\
Period excess rainfall & 2 & 2 & 0 \\
Extreme drought & 1 & 3 & 1 \\
Extreme cold & 0 & 0 & 0 \\
Hail storms & 0 & 0 & 0 \\
Strong winds & 0 & 0 & 0 \\
Flooding & 3 & 1 & 1 \\
Earthquake & 0 & 0 & 0 \\
Volcanic & 0 & 0 & 0 \\
\hline
\end{tabular}

\subsection{Biological and Environmental Related Risk}

The most disturbing risk issues in agricultural supply chain in Ghana concerning biological and environmental related risk are raised by pests and diseases associated with the operations of the agricultural supply chain (Table 3). Other risk issues of concern in the agricultural supply chain in Ghana relating to biological and environmental related risks are contamination affecting food safety and contamination and degradation of production and processing processes (Table 3). Human contamination and illnesses and contamination related to poor sanitation rarely occur and has no severity threats on agricultural supply chain (Table 3). The participant in the agricultural supply chain have strong management/control abilities of biological and environmental risk developing from contamination related to poor sanitation, human contamination and illnesses and contamination affecting food safety. However, their ability to management/control risk emerging from contamination and degradation of production and processing processes is weak. 
Table 3. Biological and Environmental related risk

\begin{tabular}{llll}
\hline & Probability & Severity & $\begin{array}{l}\text { Management/control } \\
\text { score }\end{array}$ \\
\hline $\begin{array}{l}\text { Pests and diseases } \\
\begin{array}{l}\text { Contamination related to poor } \\
\text { sanitation }\end{array}\end{array}$ & 3 & 2 & 2 \\
$\begin{array}{l}\text { Human contamination and } \\
\text { illnesses }\end{array}$ & 1 & 0 & 3 \\
$\begin{array}{l}\text { Contamination affecting food } \\
\text { safety }\end{array}$ & 1 & 0 & 3 \\
$\begin{array}{l}\text { Contamination and degradation } \\
\text { of production and processing } \\
\text { processes }\end{array}$ & 1 & 3 & 3 \\
\hline $\begin{array}{l}\text { Related Risk } \\
\text { n }\end{array}$ & & 1 & 2 \\
\hline
\end{tabular}

\subsection{Market Related Risk}

The agricultural supply chain in Ghana is highly influence by market related risks. The results in identifying market related risks indicates that demand related risk such as unanticipated or very volatile customer demand and insufficient or distorted information from customers about orders or demand quantities are highly probable. Although the probability is high, its severity is medium in agricultural supply chain (Table 4). Other demand related risk such changes in enterprise/supply chain reputation and changes in enterprise/supply chain dependability do occur but with low severity on the agricultural supply chain (Table 4).

On the supply related risk of the market, the topmost risk issues in agricultural supply chain risk in Ghana are unanticipated or very volatile customer supply, poor logistics performance of suppliers (delivery dependability), sudden default of a supplier (e.g., due to bankruptcy) and fluctuations in input price. These supply related risks shown to be highly probable and medium severity impact on the chain (Table 4). Other supply related issues such as supplier quality problems and poor logistics performance of logistics service providers are also of concern to agricultural supply chain in Ghana (Table 4). The abilities to manage/control market related to risk is generally weak in agricultural supply chain in Ghana. Participants' ability to manage /control of all the parameters studied were weak. They also have no abilities to control risk emerging from insufficient or distorted information your customers about orders or demand quantities and fluctuations in input price (Table 4).

Table 4. Market related risk

\begin{tabular}{llll}
\hline $\begin{array}{l}\text { Demand related risk } \\
\text { Unanticipated or very volatile }\end{array}$ & Probability & Severity & $\begin{array}{l}\text { Management } \\
\text { /control score }\end{array}$ \\
\hline $\begin{array}{l}\text { customer demand. } \\
\begin{array}{l}\text { Insufficient or distorted information } \\
\text { from your customers about orders or } \\
\text { demand quantities. }\end{array}\end{array}$ & 4 & 2 \\
$\begin{array}{l}\text { changes in enterprise/supply chain } \\
\text { reputation } \\
\text { changes in enterprise/supply chain } \\
\text { dependability }\end{array}$ & 1 & 2 & 1 \\
$\begin{array}{l}\text { Supply side } \\
\text { Unanticipated or very volatile } \\
\text { customer Supply. }\end{array}$ & 1 & 1 & 2 \\
$\begin{array}{l}\text { Poor logistics performance of suppliers } \\
\text { (delivery dependability. }\end{array}$ & 3 & 1 & 2 \\
$\begin{array}{l}\text { Supplier quality problems. } \\
\text { Sudden default of a supplier (e.g., due } \\
\text { to bankruptcy). }\end{array}$ & 3 & 2 & 2 \\
$\begin{array}{l}\text { Poor logistics performance of logistics } \\
\text { service providers. }\end{array}$ & 2 & 2 & 2 \\
$\begin{array}{l}\text { Capacity fluctuations or shortages on } \\
\text { the supply markets. }\end{array}$ & 3 & 2 & 2 \\
\begin{tabular}{l} 
Fluctuations in input price \\
\hline
\end{tabular} & 3 & 2 & 2 \\
\hline
\end{tabular}




\subsection{Logistic and Infrastructure Related Risk}

From the result, agricultural supply chain in Ghana is influence by logistics and infrastructure related risks. The chain is highly affected by logistics and infrastructure risks cause by changes in transport cost, energy costs and infrastructure and services cost (Table 4). Other risks cause by loss of own production capacity due to local disruptions (such as labour strike, industrial accidents), perturbation or breakdown of internal IT infrastructure (caused by computer viruses, software bugs) as well as loss of own production capacity due to technical reasons (e.g., machine deterioration), perturbation or breakdown of external IT infrastructure and communication cost in general infrequently occur and also leads to low severity on agricultural supply chain in Ghana (Table 5). The agricultural supply chain participants in Ghana have no abilities in managing/control of risks that erupts from changes in transport cost communication cost, conflicts, labor disputes affecting transport, down time or loss of own production capacity due to local disruptions (e.g., labor strike, fire, explosion, industrial accidents), perturbation or breakdown of internal IT infrastructure (e.g., caused by computer viruses, software bugs). Also they can weakly manage/control those that emerge from energy cost and infrastructure and services cost.

However, participants in the agricultural supply chain in Ghana strongly manage/control risks as a results of loss of own production capacity due to technical reasons and undependable risk (Table 5).

Table 5. Logistic and infrastructure related risk

\begin{tabular}{|c|c|c|c|}
\hline & Probability & Severity & $\begin{array}{l}\text { Management } \\
\text { /control score }\end{array}$ \\
\hline & 4 & 2 & 1 \\
\hline \multicolumn{4}{|l|}{ Changes in transport cost } \\
\hline Communication cost & 1 & 1 & 1 \\
\hline Energy costs & 4 & 2 & 2 \\
\hline Undependable transport & 2 & 2 & 3 \\
\hline $\begin{array}{l}\text { Conflicts, labor disputes affecting } \\
\text { transport, }\end{array}$ & 0 & 0 & 1 \\
\hline Infrastructure and services cost & 3 & 3 & 2 \\
\hline $\begin{array}{l}\text { Down time or loss of own } \\
\text { production capacity due to local } \\
\text { disruptions (e.g., labor strike, } \\
\text { fire, explosion, industrial } \\
\text { accidents). }\end{array}$ & 1 & 1 & 1 \\
\hline $\begin{array}{l}\text { Perturbation or breakdown of } \\
\text { internal IT infrastructure (e.g., } \\
\text { caused by computer viruses, } \\
\text { software bugs). }\end{array}$ & 1 & 1 & 1 \\
\hline $\begin{array}{l}\text { Loss of own production capacity } \\
\text { due to technical reasons (e.g., } \\
\text { machine deterioration). }\end{array}$ & 1 & 1 & 3 \\
\hline $\begin{array}{l}\text { Perturbation or breakdown of } \\
\text { external IT infrastructure. }\end{array}$ & 1 & 1 & 1 \\
\hline
\end{tabular}

\subsection{Political Related Risks}

From our results, with the exception of changes in the political environment due to the introduction of new laws stipulations, other risks issues relating to political risk hardly occur and have low severity on agricultural supply chain in Ghana (Table 6). Even though participants in agricultural supply chain hardly face risks associated with politics, they may have no abilities to manage/control such risks (Table 6). 
Table 6. Political related risks

\begin{tabular}{llll}
\hline & Probability & Severity & $\begin{array}{l}\text { Management } \\
\text { /control score }\end{array}$ \\
\hline $\begin{array}{l}\text { Political instability, war, civil } \\
\text { unrest or other socio- political } \\
\text { crises. }\end{array}$ & 0 & 0 & 1 \\
$\begin{array}{l}\text { Interruption of trade due to } \\
\text { disputes with other countries. }\end{array}$ & 0 & 0 & 1 \\
$\begin{array}{l}\text { Nationalization/confiscation of } \\
\text { assets, especially for foreign } \\
\text { investors. }\end{array}$ & 0 & 0 & 1 \\
$\begin{array}{l}\text { Changes in the political } \\
\text { environment due to the } \\
\text { introduction of new laws } \\
\text { stipulations }\end{array}$ & 1 & 0 & 1 \\
\hline
\end{tabular}

\subsection{Policy and Institutional Related Risk}

Our findings on policies and institutional policies risk indicate that risks cause by changings and/or uncertain monetary, fiscal and tax policies and weak institutional capacity to implement regulatory mandates are the most probable risks issues and has large severity in agricultural supply chain in Ghana. Meanwhile participants have weak management/control over these risks (Table 7). Other risk such as changing/uncertain regulatory and legal policies and enforcement, changing and/or uncertain trade and market policies changing and/or uncertain land policies and tenure system governance related uncertainty are not only having low probability but has low severity in agricultural supply chain in Ghana. However even with their low rate of occurring participants in agricultural supply chain have small ability to manage/control them (Table 7).

Table 7. Policy and institutional related risk

\begin{tabular}{llll}
\hline & Probability & Severity & $\begin{array}{l}\text { Management } \\
\text { /control score }\end{array}$ \\
\hline $\begin{array}{l}\text { Changing and/or uncertain } \\
\text { monetary, fiscal and tax policies, } \\
\begin{array}{l}\text { Changing and/or uncertain } \\
\text { regulatory and legal policies, and } \\
\text { enforcement (e.g. subsidies, }\end{array}\end{array}$ & 2 & 3 & 2 \\
$\begin{array}{l}\text { regulations for food safety } \\
\text { and environmental regulations) } \\
\text { Changing and/or uncertain trade } \\
\text { and market policies }\end{array}$ & 1 & 1 & 2 \\
$\begin{array}{l}\text { Changing and/or uncertain land } \\
\text { policies and tenure system } \\
\text { Governance related uncertainty } \\
\text { (e.g., corruption) }\end{array}$ & 1 & 3 & 1 \\
$\begin{array}{l}\text { Weak institutional capacity to } \\
\text { implement regulatory mandates }\end{array}$ & 2 & 1 & 1 \\
\hline
\end{tabular}

\subsection{Financial Related Risk}

Inadequate financial support is the major financial related risk with high probability and large severity on agricultural supply chain in Ghana (Table 8). However, financial risks as results of delays in accessing financial support, uncertain financial support (credit) and period change/ uncertain interest and exchange rate policies are of concern to agricultural supply chain in Ghana (Table 8). Averagely participants have weak abilities in managing/control financial related risks in agricultural supply chain in Ghana. They have no abilities in management/control of period change/uncertain interest and exchange rate policies (Table 8). 
Table 8. Financial related risk

\begin{tabular}{llll}
\hline & Probability & Severity & $\begin{array}{l}\text { Management } \\
\text { /control score }\end{array}$ \\
\hline $\begin{array}{l}\text { Inadequate financial support } \\
\begin{array}{l}\text { Delays in accessing financial } \\
\text { support }\end{array}\end{array}$ & 3 & 3 & 2 \\
$\begin{array}{l}\text { Uncertain financial support } \\
\text { (credit) }\end{array}$ & 3 & 3 & 2 \\
$\begin{array}{l}\text { Period change/ uncertain interest } \\
\text { and exchange rate policies }\end{array}$ & 2 & 2 & 2 \\
\hline $\begin{array}{l}\text { ional and Management Related Risk } \\
\text { nand }\end{array}$ & 2 & 1 \\
\hline
\end{tabular}

\subsection{Operational and Management Related Risk}

From the result on operational and management related risk, forecast and planning errors, not prepared to change product, process, markets and inability to adapt to changes in cash are the major probable risks with large severity of agricultural supply chain in Ghana (Table 9). Other risk in the chain emerges from issues associated with poor management decisions in asset allocation and livelihood/enterprise selection, poor decision making in use of inputs, poor quality control, breakdowns in farm or firm equipment and use of outdated seeds/Input (Table 9). The management and control of operation and management related risks seems encouraging. There are indications of medium - strong management/control of risk emerging from all the variables studied except risks emerging from breakdowns in farm or firm equipment (Table 9).

Table 9. Operational and management related risk

\begin{tabular}{llll}
\hline & Probability & Severity & $\begin{array}{l}\text { Management } \\
\text { /control score }\end{array}$ \\
\hline $\begin{array}{l}\text { Poor management decisions in } \\
\text { asset allocation and } \\
\text { livelihood/enterprise selection, } \\
\begin{array}{l}\text { Poor decision making in use of } \\
\text { inputs, }\end{array}\end{array}$ & 1 & 1 & 3 \\
$\begin{array}{l}\text { Poor quality control, } \\
\begin{array}{l}\text { Forecast and planning errors, } \\
\text { Breakdowns in farm or firm } \\
\text { equipment, }\end{array}\end{array}$ & 2 & 2 & 3 \\
$\begin{array}{l}\text { Use of outdated seeds/Input } \\
\text { Not prepared to change product, } \\
\text { process, markets, }\end{array}$ & 2 & 2 & 3 \\
$\begin{array}{l}\text { Inability to adapt to changes in } \\
\text { cash and labor flows, etc. }\end{array}$ & 2 & 3 & 3 \\
\hline
\end{tabular}

\section{Discussion and Managerial Implications}

From the results there is indication that not all weather related risks influencing general supply affects agricultural supply chain in Ghana. The geographical position of the country explains the probability and severity of periodic deficit/excess of rainfall risks of agricultural supply chain in the area. According to Stutley (2010) agriculture in Ghana is prone to a range of climatic hazards including most notably drought and excess rain/ flood. It will be prudent for managers, decision makers and investors in particular to consider weather issues such as periodic deficit/excess of rainfall and flooding when operating in agricultural supply chain in Ghana.

Even though there should be pre-planned issues concerning biological and environmental related risk issues in agricultural supply chain, pest and diseases control are highly probable but have medium severity on the chain and weak management/control abilities. It's prudent for participants in the supply chain to adopt sound pest and diseases prevention and management/control programs to improve biological and environmental risks management/control in Ghana agricultural supply chain.

Just like any other supply chain, agricultural supply chain in Ghana is inevitable of market related risks, however investors should be mindful and strategize for market related risk arising from unanticipated/very volatile customer demand/customer supply, insufficient/distorted information from customers about orders or demand quantities, poor 
logistics performance of suppliers and sudden default and fluctuations in input price of a supplier are of high occurrence. An effective management of these risks could lead to near perfect supply chain operations.

It will be of great importance for new investors and managers/decision makers to consider logistics and infrastructure related risks when investing in supply chain operations. In Ghana agricultural supply chain the highly probably risk issues related to logistics and infrastructure are changes in transport cost, energy costs an infrastructure and services cost. An effective management of these risks could increase the benefits in agricultural supply chain in Ghana.

Issues concerning agricultural supply chain risk based on political related risks are virtually absent in agricultural supply chain in Ghana due to their low probability and severity. This may be due to the outstanding performance or the consistent interest of successive political leaders in promoting agricultural industries in the country.

It will be added advantage for managers, decision makers and other chain participants to strategize to management/control risk sources related to policies and institutional risks such as changing and/or uncertain monetary, fiscal and tax policies and enforcement and weak institutional capacity to implement regulatory mandates associated with agricultural supply chain risk to achieve better performance in the agricultural supply chain in Ghana.

The results of financial related risks imply financial institutions may be unwilling to invest agricultural supply chain participants. Probably, they see it as highly risky venture. However, earlier studies have indicated that agricultural credit is profitable if producers are well integrated into a viable value chain (Shwedel, 2007). The participants in chain should strategies for periodic change/uncertain interest rate and exchange rate policies to effectively manage their agricultural supply chain in Ghana.

Poor quality control, forecast and planning errors, breakdowns in farm or firm equipment, use of outdated seeds/input, not prepared to change product, process, markets, inability to adapt to change in cash and labor flows are the most probably risk associated with operation and management related risk in agricultural supply chain in Ghana. Finding the antidotes to these risks will be beneficial to the supply chains participants.

\section{Conclusion and Future Research}

Agricultural supply chain in Ghana just as any other supply chain is evitable of risk. With the exception of weather related risks (extreme cold, hail storms, strong winds, flooding, earthquake, volcanic) which are geographically influenced and political related risks (political instability, war, civil unrest or other socio- political crises, interruption of trade due to disputes with other countries and nationalization/confiscation of assets, especially for foreign investors) all other risk issues in supply chain field raised in this paper affects agricultural supply chain in Ghana. However, risks affecting the agricultural supply chain differ in terms of probability and severity. We can infer from this paper that most agricultural risks identified have low or no severity. For instance while biological and environmental risks such as contamination related to poor sanitation and human contamination and illnesses are probable in the Ghana agricultural chain but they no severity in the chain. Whiles some risk sources could be manage/control, others have no management/control strategies/abilities. For instance participants in the chain have no abilities to manage/control financial related risks such as inadequate financial support. However the participants in chain weakly manage/control financial related risks such as delays in accessing financial support, uncertain financial support (credit), period change/ uncertain interest and exchange rate policies.

A further empirical research to investigate the relationship between a set of agricultural risks identified which are supposed to stimulate the risk in agricultural supply chain in Ghana and its significant influence on chains' performance will be of immense help to the participants in the chain in managing/controlling risks associated with the operations of the chain.

\section{Refferences}

Aghazadeh, S. (2004). Improving logistics operations across the food industry supply chain. International Journal of contemporary Hospitality Management, 16(4), 263-268. http://dx.doi.org/10.1108/09596110410537423

Agrell, P.J., Lindroth, R., \& Norrman, A. (2004). Risk, information and incentives in telecom supply chains. International Journal of Production Economics, 90, 1-16. http://dx.doi.org/10.1016/S0925-5273(02)00471-1

Akkerman, R., Farahani, P., \& Grunow, M. (2010). Quality, safety and sustainability in food distribution: A review of quantitative operations management approaches and challenges. OR Spectrum, 32, 863-904. http://dx.doi.org/10.1007/s00291-010-0223-2

Baird, I.S., \& Thomas, H. (1990). What is risk anyway? In Bettis, R.A., \& Thomas, H. (Eds.), Risk, Strategy, and Management (pp. 21-52). JAI Press, London. 
Benson, C., \& Clay, E. (1998). The Impact of Drought on Sub-Saharan African Economies: A Preliminary Examination. World Bank Technical Paper 401, Washington, DC. http://dx.doi.org/10.1596/0-8213-4180-4

Brimer, R. C. (1995). Logistics networking. Logistics Information Management, 8, 8-11. http://dx.doi.org/10.1108/09576059510091850

Bryceson K. P., \& Smith C. S. (2008). Abstraction and Modelling of Agri-Food Chains as Complex Decision Making Systems. Proceedings of the EAAE Conference on System Dynamics and Innovation in Food Networks, pp. 18-22, Innsbruck-Igls, Austria.

Carter, C.R., \& Rogers, D.S. (2008). A framework of sustainable supply chain management: moving toward new theory. International Journal of Physical Distribution and Logistics Management, 38(5), 360-387. http://dx.doi.org/10.1108/09600030810882816

Checa, N., Maguire, J., \& Barney, J. (2003). The new world disorder. Harvard Business Review, 81(8), $70-79$.

Chopra, S., \& Sodhi, M. (2004). Managing risk to avoid supply-chain breakdown. Sloan Management Review, 46(1), 53-61.

Christopher, M. (2005). Logistics and Supply Chain Management. Prentice Hall, London.

Christopher, M., \& Lee, H. L. (2004). Mitigating Supply Chain Risk through Improved Confidence. International Journal of Physical Distribution and Logistics Management, 34(5), 388-396. http://dx.doi.org/10.1108/09600030410545436

Coleman, L. (2006). Frequency of Man-Made Disasters in the 20th Century. Journal of Contingencies and Crisis Management, 14(1), 3-11. http://dx.doi.org/10.1111/j.1468-5973.2006.00476.x

Craighead, C.W., Blackhurst J., Rungtusanatham, J. M., \& Handfield, R. B. (2007). The Severity of Supply Chain Disruptions: Design Characteristics and Mitigation Capabilities. Decision Sciences, 38(1), 131-156. http://dx.doi.org/10.1111/j.1540-5915.2007.00151.x

Cudahy, G., Mulani, N., \& Cases, C. (2008). Mastering global operations in multipolar world. Supply Chain Management Review, 12(2), 22-29.

Ding, Q., Dong, L., \& Kouvelis, P. (2007). On the integration of production and financial hedging decisions in global markets. Operations Research, 55(3), 470-489. http://dx.doi.org/10.1287/opre.1070.0364

Dorosh, P.A., Dradri, S., \& Haggblade, S. (2009). Regional trade, government policy and food security: Recent evidence from Zambia. Food Policy, 34(4), 350-366. http://dx.doi.org/10.1016/j.foodpol.2009.02.001

Ellram L. (1996). The use of case study method in logistics research. Journal of business logistics, 17(2).

Fitzgerald, K.R. (2005). Big savings, but lots of risk. Supply Chain Management Review, 9(9), 16-20.

Ghana Statistical Service. (2008). Ghana Living Standards Survey. Fifth Round (GLSS 5), CD-Rom, September.

Ghana Statistical Service. (2012). National Accounts and Economic Indicators Division. Retrieved March 15, 2014, from www.statsghana.gov.gh/doc files/GDP/revised_gdp_2012.pdf

Hardaker J.B., Huirne R.B.M., Anderson J.R., \& Lien G. (2004). Coping with Risk in agriculture (2nd ed.). Wallingford: CABI Publishing. http://dx.doi.org/10.1079/9780851998312.0000

Harland, C., Richard B., \& Helen, W. (2003). Risk in Supply Networks. Journal of Purchasing and Supply Management, 9(2), 51-62. http://dx.doi.org/10.1016/S1478-4092(03)00004-9

Hartley-Urquhart, R. (2006, September). Managing the financial supply chain. Supply Chain Management Review, $18-25$.

Helferich, O. K., \& Cook, R. (2002). Securing the Supply Chain. Oak Brook, IL: Council of Logistics Management.

Hendricks, K. B., \& Singhal, V. R. (2003). The Effect of Supply Chain Glitches on Shareholder Wealth. Journal of Operations Management, 21(5), 501-522. http://dx.doi.org/10.1016/j.jom.2003.02.003

Hendricks, K. B., \& Singhal, V. R. (2005a). An Empirical Analysis of the Effects of Supply Chain Disruptions on Long-Run Stock Price Performance and Equity Risk of the Firm. Production and Operations Management, 14(1), 35-52. http://dx.doi.org/10.1111/j.1937-5956.2005.tb00008.x

Hendricks, K. B., \& Singhal, V. R. (2005b). Association between Supply Chain Glitches and Operating Performance. Management Science, 51(5), 695-711. http://dx.doi.org/10.1287/mnsc.1040.0353 
Hendricks, K., \& Singhal, V. (2005). An empirical analysis of the effect of supply chain disruptions on long-run stock price performance and equity risk of the firm. Production and operations Management, 25-53.

Holzmann, R., \& S.L. Jørgensen. (2000). Social Risk Management: A New Conceptual Framework for Social Protection and Beyond. Social Protection Discussion Paper No. 0006. The World Bank: Washington, D.C.Retrieved from www.worldbank.org/SP

Jaffee, S., Siegel, P., \& Andrews, C. (2010). Rapid Agricultural Supply Chain Risk Assessment: A Conceptual Framework. The World Bank. Washington. D.C.

Jemison, D. B. (1987). Risk and the Relationship among Strategy, Organizational Processes, and Performance. Management science, 33(9), 1087-1101. http://dx.doi.org/10.1287/mnsc.33.9.1087

Juttner, U. (2005). Supply chain risk management: Understanding the business requirements from a practitioner perspective. International Journal of Logistics Management, 16(1), 120-141. http://dx.doi.org/10.1108/09574090510617385

Jüttner, U., Helen, P., \& Martin, C. (2003). Supply Chain Risk Management: Outlining an Agenda for Future Research. International Journal of Logistics: Research and Applications, 6(4), 197-210. http://dx.doi.org/10.1080/13675560310001627016

Kersten, W., \& Blecker, T. (2006). Managing risks in supply chains: How to build reliablecollaboration in logistics. Erich Schmidt Verlag, Berlin.

Kinsey, J.D. (2001). The new food economy: Consumers, farms, pharms and science. American Journal of Agricultural Economics, 83(5), 1113-1130. http://dx.doi.org/10.1111/0002-9092.00259

Knemeyer, A.M., Zinna, W., \& Eroglu, C. (2009). Proactive planning for catastrophic events in supply chains. Journal of Operations Management, 27, 141-153. http://dx.doi.org/10.1016/j.jom.2008.06.002

Kouvelis, P., Chambers, C., \& Wang, H. (2006). Supply chain management research and production and operations management: Review, trends, and opportunities. Production and Operations Management, 15(3), 449-469. http://dx.doi.org/10.1111/j.1937-5956.2006.tb00257.x

Ksoll, C., Macchiavello, M., \& Morjaria, A. (2009). Guns and Roses: The Impact of the Kenyan Post-Election Violence on Flower Exporting Firms. Centre for the Study of African Economies (CSAE), Oxford University. CSAE WPS/2009-06 (May).

LaLonde, B.J. (2004, November/December). A crisis in transportation. Supply Chain Management Review, 7-8.

LaLonde, B.J. (2005, May/June). Time to get serious about energy. Supply Chain Management Review, 8-9.

Lee, H. L., Padmanabhan, V., \& Seungjin, W. (1997). Information Distortion in a Supply Chain: The Bullwhip Effect. Management Science, 43(4), 546-558. http://dx.doi.org/10.1287/mnsc.43.4.546

Lowe, T. J., \& Preckel, P. V. (2004). Decision technologies for agribusiness problems: A brief review of selected literature and a call for research. Manufacturing \& Service Operations Management, 6(3), 201-208. http://dx.doi.org/10.1287/msom.1040.0051

Maccini, S., \& Yang, D. (2009). Under the Weather: Health, Schooling, and Economic Consequences of Early-Life Rainfall. American Economic Review, 99(3), 10-26. http://dx.doi.org/10.1257/aer.99.3.1006

Manuj, I., \& Mentzer, J.T. (2008). Global supply chain risk management. Journal of Business Logistics, 29, 133-154. http://dx.doi.org/10.1002/j.2158-1592.2008.tb00072.x

Martha, J., \& Subbakrishna S. (2002). Targeting a Just-in-Case Supply Chain for the Inevitable Next Disaster. Supply Chain Management Review, 6(5), 18-23.

McKinnon, A. (2006). Life without trucks: The impact of a temporary disruption of road freight transport on a national economy. Journal of Business Logistics, 27, 227-250. http://dx.doi.org/10.1002/j.2158-1592.2006.tb00224.x

Meuwissen, M.P.M., Huirne, R.B.M., \& Hardaker, J.B. (2001). Risks and risk management strategies; an analysis of Dutch livestock Farmers. Livestock Production Science, 69, 43-53. http://dx.doi.org/10.1016/S0301-6226(00)00247-5

Minogue, M. (2005). Apples and Oranges - Comparing International Experiences in Regulatory Reform, Occasional Lecture 13, Bath. Centre for the Study of Regulated Industries, University of Bath 
Murphy, S. (2007, December). The supply chain in 2008. Supply Chain Management Review, 4-7.

Nagurney, A., Jose, C., June, D., \& Ding, Z. (2005). Supply Chain Networks, Electronic Commerce and Supply Side and Demand Side Risk. European Journal of Operational Research, 164(1), 120-142. http://dx.doi.org/10.1016/j.ejor.2003.11.007

Nahmias, S. (2011). Perishable Inventory Systems. Springer, New York, USA. http://dx.doi.org/10.1007/978-1-4419-7999-5

Neiger, D., Rotaru, K., \& Churilov, L. (2009). Supply chain risk identification with value- focused process engineering. Journal of Operations Management, 27(2), 154-168. http://dx.doi.org/10.1016/j.jom.2007.11.003

Niemira, M. P. (2005). Weather matters. International Council of Shopping Centers. Research Review, 12(2), 23-27.

Palinkas P., \& C. Székely. (2008). Farmers' perception on risk and crisis management. In Meuwissen, M.P.M., M.A.P.M. van Asseldonk and R.B.M. Huirne (Eds.), Income Stabilization in European Agriculture: Design and Economic Impact of Risk Management Tools. Wageningen Academic Publishers, Wageningen.

Paulson, U. (2005). Developing a supply chain flow risk model. NOFOMA 2005 Conference, Copenhagen, 9-10 June 2005.

Peck, H. (2006). Reconciling supply chain vulnerability, risk and supply chain management. International Journal of Logistics: Research and Application, 9(2), 127-142. http://dx.doi.org/10.1080/13675560600673578

Peck, H., Abley, J., Christopher, M., Haywood, M., Saw, R., Rutherford, C., \& M., Strathern. (2003). Creating Resilient Supply Chains: A Practical Guide. Cranfield University, Cranfield School of Management, UK.

Quinn, F. (2006). Risky business. Supply Chain Management Review, 10(4), 1-5.

Rice, J.B., \& Caniato, F. (2003). Building a secure and resilient supply network. Supply Chain Management Review, $7(5), 22-30$.

Sheffi, Y., \& Rice, J.B. (2005). A supply chain view of the resilient enterprise. MIT Sloan Management Review, 47, 41-48.

Shwedel, K. (2007). Value chain financing a strategy for an orderly competitive integrated market. Retrieved March 15,2014 , from www.ruralfi nance.org/id/54079

Siegel, P. B. (2005). Managing agricultural production risk: Innovations in developing Countries. Commodity Risk Management Group, Agricultural and Rural Development Department, World Bank Report No. 32727, Washington D.C.

Siegel, P.B., \& J. Alwang. (1999). An asset-based approach to social risk management: A conceptual framework. Social Protection Discussion Paper No. 9926. The World Bank: Washington, D.C. Retrieved from www.worldbank.org/SP

Sodhi, M.S. (2005). Managing demand risk in tactical supply chain planning for a global consumer electronics $\begin{array}{lllll}\text { company. } & \text { Production }\end{array}$ http://dx.doi.org/10.1111/j.1937-5956.2005.tb00010.x

Sodhi, M.S., Son, B., \& Tang, C.S. (2012). Researchers' perspectives on supply chain risk management. Production and Operations Management, 21(1), 1-13. http://dx.doi.org/10.1111/j.1937-5956.2011.01251.x

Spekman, R. E., \& David, E. W. (2004). Risky Business: Expanding the Discussion on Risk and the Extended Enterprise. International Journal of Physical Distribution and Logistics Management, 34(5), 414-433. http://dx.doi.org/10.1108/09600030410545454

Stalk, G. (2006). The costly secret of China sourcing. Harvard Business Review, 84(2), 64-66.

Starr-McCluer, M. (2000). The Effects of Weather on Retail Sales, Federal Reserve Board of Finance and Economics. Discussion Series Working Paper 2000-08, Federal Reserve Board of Governors, Washington, D.C.

Stiglitz, J. (1998). Private Uses of Public Interests: Incentives and Institutions, Governors, Washington, D.C. Journal of Economic Perspectives, 12(2), 3-22. http://dx.doi.org/10.1257/jep.12.2.3

Stutley, C. (2010). Innovative Insurance Products for the Adaptation to Climate Change Project Ghana (IIPACC): Crop Insurance $\quad$ Feasibility $\quad$ Study. $\quad$ Retrieved from http://seguros.riesgoycambioclimatico.org/DocInteres/eng/Ghana-Crop-Insurance.pdf

Tang, C.S. (2006a). Perspectives in supply chain risk management. International Journal of Production Economics, 
103, 451-488. http://dx.doi.org/10.1016/j.ijpe.2005.12.006

Tang, C.S. (2006b). Robust strategies for mitigating supply chain disruptions. International Journal of Logistics: Research and Application, 9(1), 33-45. http://dx.doi.org/10.1080/13675560500405584

Tang, O., \& Musa, S.N. (2011). Identifying risk issues and research advancements in supply chain risk management. International Journal of Production Economics, 133, 25-34. http://dx.doi.org/10.1016/j.ijpe.2010.06.013

Tarantilis, C. D., Diakoulaki, D., \& Kiranoudis, C. T. (2004). Combination of geographical information system and efficient routing algorithms for real life distribution operations. European Journal of Operational Research, 152, 437-453. http://dx.doi.org/10.1016/S0377-2217(03)00035-3

USDA. (2012). Farm and Impact. Retrieved March 15, 2014, from http://www.ers.usda.gov/topics/in-the-news/us-drought-2012-farm-and-food-impacts.aspx

Wagner, S.M., \& Bode, C. (2008). An empirical examination of supply chain performance along several dimensions of risk. Journal of Business Logistics, 29(1), 307-325. http://dx.doi.org/10.1002/j.2158-1592.2008.tb00081.x

Wagner, S.M., \& Johnson, L. J. (2004). Configuring and Managing Strategic Supplier Portfolios. Industrial Marketing Management, 33(8), 717-730. http://dx.doi.org/10.1016/j.indmarman.2004.01.005

World Bank. (1995). Bureaucrats in Business: The Economics and Politics of Government Ownership. Oxford: Oxford University Press for the World Bank.

World Bank. (2001). World Development Report 2000/2001: Attacking Poverty. New York: Oxford University Press.

Yin, R.K. (1984). Case Study Research: Design and Methods. Beverly Hills; London. SAGE

Zinyama, F. (2007, February 27). WFP awards NMC Zim maize export contract, p11. The Post.

Zsidisin, G., \& Ellram L.A. (2003). An Agency Theory Investigation of Supply Risk Management. Journal of Supply Chain Management, 39(3), 15-27. http://dx.doi.org/10.1111/j.1745-493X.2003.tb00156.x

Zsidisin, G.A. (2003). A Grounded Definition of Supply Risk. Journal of Purchasing and Supply Management, 9(5/6), 217-224. http://dx.doi.org/10.1016/j.pursup.2003.07.002

Zsidisin, G.A., Melnyk, S.A., \& Ragatz, G.L., (2005). An institutional theory perspective of business continuity planning for purchasing and supply management. International Journal of Production Research, 43(16), 3401-3420. http://dx.doi.org/10.1080/00207540500095613

Zsidisin, G.A., Panelli, A., \&Rebecca U. (2000). Purchasing Organization Involvement in Risk Assessments, Contingency Plans, and Risk Management: An Exploratory Study. Supply Chain Management: An International Journal, 5(4), 187-197. http://dx.doi.org/10.1108/13598540010347307 